\title{
DIÁlOGO SOBRE PRÁTICA PEDAGÓGICA: UM RELATO DE EXPERIENCIA
}

\section{Relato de Experiência}

Marciene Pacheco ${ }^{1}$; Emanuela Vitória Dias Morais²; Albertina Marília Alves Guedes ${ }^{3}$ (Orientadora)

\section{INTRODUÇÃO}

O professor pode utilizar de estratégias de ensino diversas atividades possibilitando que o aluno possa apreender e compreender o conteúdo ministrado em sala de aula de maneiras diferenciadas (PERRENOUD, 2002). Além disso, considerando que o professor exerce o papel de mediador dos conteúdos ministrados em sala de aula, Piletti (2010) ainda apresenta que o papel do professor em sala de aula também consiste em ajudar o aluno a assimilar os conteúdos ministrados em sala de aula. Desse modo, podemos compreender que metodologias de ensino diz respeito da utilização ações pedagógicas traçadas e/ou planejadas e vivenciadas pelo professor viando orientar e direcionar o processo de ensino-aprendizagem.

\section{RELATO DE EXPERIÊNCIA}

O presente relato diz respeito a uma experiência vivenciada na disciplina de Prática de Ensino II na qual entrevistamos uma professora que ministra disciplinas pedagógicas nos cursos de Licenciatura em Química, Física, Música e Computação do IF Sertão PE, Campus Petrolina. Ressaltamos que antes da realização da entrevista tivemos o cuidado em agendar dia, horário e local conveniente à professora entrevistada a qual objetivou conhecer a experiência docente da referida professora sobre: metodologias de ensino; processo de ensino e aprendizagem; saber-fazer pedagógico na educação profissional; formação de professores; diálogo sobre a influência da afetividade entre professor, aluno e o conhecimento; discussão sobre interesse, motivação, diferenças no modo de aprender, e; diálogo sobre desafios e possibilidades presentes no processo de interação entre aluno, conhecimento e o contexto escolar; dentre outras. O critério exigido para a participação neste trabalho foi: ser professor que ministra a disciplina de Prática de Ensino nos cursos de Licenciatura do IF Sertão, Campus Petrolina.

As temáticas acima exposta pela professora entrevistada nos trouxe um amplo aprendizado

\footnotetext{
${ }^{1}$ Estudante do curso de Licenciatura em Computação, IF Sertão PE, Campus Petrolina. E-mail: marcienepacheco@gmail.com. ${ }^{2}$ Estudante do curso de Licenciatura em Computação, IF Sertão PE, Campus Petrolina. E-mail: vitoriadm98@gmail.com ${ }^{3}$ Professora do curso de Licenciatura em Computação, IF Sertão PE, Campus Petrolina. E-mail: albertina.guedes@ifsertao-pe.edu.br.
} 
sobre a prática pedagógicautilizada pela professora quando ministra aulas nos cursos de Licenciatura no Campus Petrolina. As palavras da professora ainda demonstra que o ensino universitário vigente no Brasil é baseado em 4 aspectos "Estude, leia, decore e repita" e traz concepções fortemente embasados no modelo de ensino tradicional. A entrevistada também ressaltou a importância de mediar o conhecimento para o aluno a partir da perspectiva da aprendizagem significativa conforme apresentado por Ausubel (1982) e Moreira (1998). Diante da observação do processo de ensino/aprendizagem, a professora ainda relatou sobre a diferenciação entre o ensino embasado apenas na perspectiva teórica e ensino embasado na perspectiva teórico e prático.

Ainda durante a entrevista a professora apresenta uma crítica com relação ao esquecimento que se tem em assuntos relevantes para a educação, diz que quando Gardner falou das múltiplas inteligências, foi uma revolução, todo mundo tinha uma receita para alguém aprender, quase 20 anos depois, até agora poucos entenderam o que é que significa isso, e dentro de todas essas revoluções o processo poderia ser bem mais dinâmico.

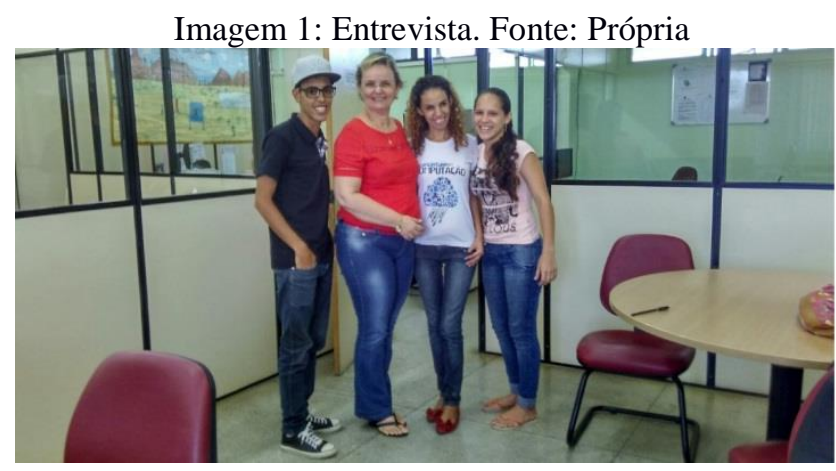

\section{CONSIDERAÇÕES FINAIS}

Nesta experiência foi possível conhecer vários aspectos do saber-fazer docente através do relato da professora entrevistada. Nessa perspectiva, pudemos conhecer relatos sobre a sua prática pedagógica, priorizando pelo aprendizado significativo, a afetividade, e buscando motivar seus alunos para o conhecimento mútuo na relação professor/aluno, efetivando um equilíbrio entre o ensino e a aprendizagem no contexto educacional. Por fim, percebemos que a professora entrevistada busca exercer um papel significativo na formação dos licenciandos ao ministrar a disciplina de Prática de Ensino nos cursos de Licenciatura do IF Sertão PE, Campus Petrolina.

\section{REFERÊNCIAS}

AUSUBEL, D. P. A aprendizagem significativa: a teoria de David Ausubel. São Paulo: Moraes, 1982.

MOREIRA, M. A. Aprendizagem significativa. Brasília: Ed. da UnB, 1998.

VYGOTSKY, L. S. A formação Social da Mente. São Paulo: Martins Fontes, 1984.

GARDNER, H. Inteligências Múltiplas: a Teoria na Prática. Porto Alegre: Artes Médicas, 
1995.

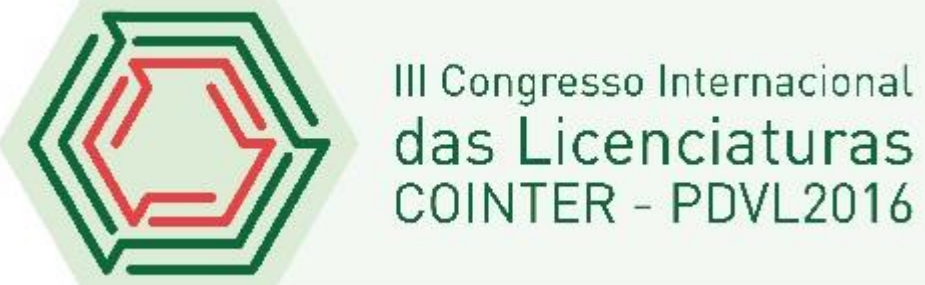

